with-an addition of 1895-a paper of essays having "reference to the fundamental principles, history, philosophy or applications of the Mechanical Sciences".

Meanwhile, Prof. Stuart had resigned and, to quote the "University Calendar", in "1890 J. A. Ewing, B.Sc. Edinb." had been appointed professor. He came, personally unknown to us, but with a distinguished career as a teacher at Tokyo and Dundee, a pupil of Lord Kelvin, the author of papers on magnetism of outstanding merit. In 1881 he had described the effects which follow the application of a cyclical process of magnetisation to iron and other material, that tendency of the magnetisation to lag behind the application of the magnetising force, to which he gave the name of hysteresis, and in 1885 had contributed a striking paper to the Royal Society entitled "Experimental Researches in Magnetism".

Ewing established himself at once as a persona grata to the University, a colleague, soon to be our leader, whom some of us who had been active in urging that engineering should receive full recognition from the University welcomed whole-heartedly among our ranks. To his wise judgment and sane advice are due the general acceptance of the scheme of education proposed. The debt due to him by the University may perhaps be measured by the success of that scheme which, aided by his staff, Peace and Dalby and Lamb, he developed for the next thirteen years.

A committee was set up in Cambridge to obtain funds for the establishment of an adequate laboratory for the teaching of engineering in the University. Sir J. J. Thomson, Prof. Newall, Sir Napier Shaw and myself are the sole survivors. Ewing was the treasurer. We had the help of a large and distinguished general committee which contained the names of all the great engineers of the day. We stated that $£ 20,000$ would be required for the complete design, but that much could be done for $£ 4,000$ or $£ 5,000$, and with the money so raised the Engineering Laboratory made its start. What it has now become engineers are well aware.

The first Tripos examination was held in 1896, Ewing, Osborne Reynolds, and Shaw were the examiners; seven candidates passed, of whom three were placed in the first class. Now the Engineering Tripos list is among the largest in the University.

Since those days, Sir Alfred has done more great work for his country. In Cambridge he will ever be remembered as the founder of the Engineering School, the man who taught the University what science, so long at home there, might do for industry and how that task might be achieved.

R. T. Glazebrook.

\section{Sir Alfred Ewing and Naval Education}

The connexion of Sir Alfred Ewing with naval education came about through the decision of the Admiralty, in 1902, to carry out a root and branch reform of the training of officers and men in all sections of the Navy. The reform was long overdue, for even up to 1901, junior officers spent a part of their time in learning to manœuvre ships under sail, although for all practical purposes sails in warships had been obsolete for thirty years. Then, too, there was the urgent problem of the staffing of the engine rooms of the steadily increasing fleet, a problem rendered difficult by the failure of successive Boards of Admiralty to adjust the status of naval engineers in accordance with their responsibilities.

Though at the beginning of the century, naval training was discussed in many quarters, the credit for the re-organisation of naval education in 1903 to meet modern requirements belongs in the first place to Lord Fisher (then Admiral Sir John Fisher), who had recently become First Sea Lord. The first step in the reform was the publication in December 1902, over the signature of Lord Selborne, of the famous "Memorandum dealing with the Entry, Training and Employment of Officers and Men of the Royal Navy and of the Royal Marines". That memorandum stated that "In the old days it sufficed if a naval officer were a seaman; now he must be a seaman, a gunner, a soldier, an engineer, and a man of science as well"; and that "the three branches of the Service which are essential to the fighting efficiency of the Fleet-the Executive, the Engineer and the Marine" were to be recruited by one system and all officers were to be trained alike up to a certain age.

These were ideas entirely new to the Service and to carry them into effect it was obvious that the Admiralty would require a man of outstanding reputation. Their choice fell on Sir Alfred Ewing, who in the preface to his book, "An Engineer's Outlook", tells of his first visit to the Admiralty, when he met Lord Fisher, "that volcanic personality whom, later, I was to see often in quiescence and in eruption, and to learn something of his greatness". This visit led to Lord Selborne offering Sir Alfred the appointment of Director of Naval Education.

To a civilian, the task Sir Alfred undertook might well have appeared a complex one, for in the course of a few months he found himself responsible for the training given in the Royal Naval College, Greenwich, H.M.S. Britannia, the new Royal Naval College at Osborne, the Royal Naval Engineering College at Keyham, the Dockyard Schools at Portsmouth, Chatham and Devonport, various training establishments for seamen, stokers and artificers, together with the supervision of the work of some eighty naval instructors of university standing, many of whom were serving on distant stations. The SelborneFisher scheme naturally cut across many traditions and found not a few critics; while from the members of the Board of Admiralty Sir Alfred received every assistance, among those below them he was sometimes conscious of cross-currents.

From the beginning it was realised that the new system of training would have to be modified in the light of experience, and many changes have been made. It may, however, safely be said that naval education to-day owes more to the work done by Sir Alfred Ewing between 1903 and the War than to any other single individual.

Edgar C. SMith. 